\section{AERIAL NAVIGATION IN FRANCE*}

THERE has been a most interesting sitting at the Academy of Sciences, at which M. Dupuy de Lôme read a report on his newly tried and apparently successful system for steering air balloons. M. de Lome is one of the most eminent-if he is not the most eminent--of living French engineers. He was the first to apply steam to ships of war, and he was one of the earliest designers of ironclad frigates. The piercing of a tunnel under the English Channel is another of M. Dupuy de Lôme's longcherished projects, and he is one of the engineers who are about to commence that gigantic enterprise. During the siege of Paris by the Prussians, M. Dupuy de Lôme offered to construct a balloon which should have steering powers of its own, and so not be totally at the mercy of the winds. That. some sort of guiding power was required for the balloons which were despatched from Paris during its investment by the Germans is shown by the fact that, out of sixty balloons sent out during that period, no less than fifteen failed to carry their contents to a place of safety, some falling into the sea and several into the hands of the Prussians. After much tiresome delay, M. Dupuy de Lôme's plans were accepted by the Government of National Defence, a credit of 40,000 francs $(I, 600 l$.) was opened for him, and he began to construct his balloon at the Palais de l'Industrie, in the Champs Elysées. So great was the difficulty, however, in constructing an immense balloon on a totally new system, in a city completely cut off from the rest of the civilised world, that M. Dupuy de Lôme's huge machine was not ready until just four days before the capitulation. When that event took place, the balloon had to be packed up and hidden away from the prying eyes of the Germans when they partially occupied Paris. Then came the Commune, and all the disorganisation which followed. It was only after much difficulty that $\mathrm{M}$. Dupuy de Lôme obtained permission to make use of the buildings of the Fort Neuf at Vincennes, whence, on the 2 nd inst., he started on his trial trip. Before proceeding to quote from M. Dupuy de Lôme's most interesting report, it may be as well to say a few words as to the end which the eminent aëronaut has proposed to himself. $\mathrm{He}$ does not pretend to be able to make independent progress in the teeth of the wind, but only to deviate from the direct set of the wind when running before it. He does not hope ever to be able to beat to windward, but only to tack to right or left with the wind. A sailor would say that M. Dupuy de Lôme wanted to be always running free with the wind on the quarter. So if the wind set straight from Paris to Brussels, an ordinary balloon could only land at some point between Paris and Brussels, or else beyond the Belgian capital. But with a balloon constructed on M. Dupuy de Lôme's system, the arëonaut might steer his course either on the port or starboard tack, and might descend at London or Cologne, as he saw fit.

Having said this much, let me try to describe the balloon which M. Dupuy de Lôme makes use of. Let your readers imagine a gigantic egg of inflated silk, the longer axis being horizontal; to this egg is attached an oblong car, something the shape of a punt. The motive of the inventor in choosing the ovoid form was at once to obtain greater stability for the car than could be hoped for with the old balloons, and at the same time to give the least possible hold to the wind. The diameter of the balloon is about twofifths of its horizontal length from point to point. I take the following dimensions from M. Dupuy de Lôme's highly interest. ing report, read before the Academy of Sciences, only changing French metres into feet for the convenience of English readers.

Total length from end to end . . . $118 \mathrm{ft} .6 \mathrm{in}$.

Diameter at the point of greatest circumference.

Diameter of the screw

Number of blades.

Number of turns of the screw in a mi. nute, when the balloon is going eight kilometres (five miles) an hour faster than the wind
$49 \mathrm{ft} .2 \mathrm{in}$. $29 \mathrm{ft} .6$ in. $2 \mathrm{I}$
M. Dupuy de Lôme thus describes the rudder by which his balloon is steered :- "The rudder is a plain triangular surface. It is made of unvarnished calico, and is kept in its place by a horizontal yard six metres long at its lower extremity. It can

\footnotetext{
* Reprinted from the Daily Nezws.
}

turn easily on its forward extremity. The height of the rudder is five metres, and it has a superfices of fifteen metres." The car is next described-it is of wicker-work, and of sufficient size to contain comfortably the windlass for the screw, and eight men to work it ; the ventilator with which to manage the small balloon-we shall have to speak of this presently-and the man who attends to it. In all, fourteen persons can be carried in the car. The driving screw is directly carried by the car. The shaft of the screw is a hollow steel tube. This shaft is constructed so as to allow of the screw being easily dismounted when a landing is effected. The rudder is fixed to the balloon itself, and the screw, as we said, is below it, and immediately attached to the car. Two blades only are used in the screw instead of four, because when the ground is touched the two blades can be placed horizontally, so as to escape injury. Were there four blades, the screw would be almost certain to be broken whenever a landing was effected. The windlass which turns the screw is worked by four, or, if necessary, eight men, in a similar manner to the steering wheel of a ship--only the wheel is placed parallel to the axis of the car, instead of at right angles to it, in order to lessen the rolling occasioned by the movements of the men working the windlass. The material of which the envelope of the balloon is composed is white silk, weighing 52 grammes, not quite $2 \mathrm{oz}$ to the square metre, and a coarser lining weighing 40 grammes the square metre, and seven coats of india-rubber, which together weigh 180 grammes, a little over $6 \mathrm{oz}$. the square metre. Thus the whole weight of the external web of the balloon is 272 grammes, about $9 \mathrm{oz}$. to the square metre. In order to render the web of the balloon totally impermeable to the hydrogen gas with which it is inflated, the silk was painted over with a sort of gelatinous compound, invented by M. Dupuy de Lôme. The total weight of the two balloons when ready to start was 570 kilogrammes, or rather more than half a ton. The web of the balloon was reckoned to be capable of supporting a pressure of over 2,000 pounds to the square yard. I have mentioned the smaller balloon; this is, more correctly speaking, only a division as it were of the larger balloon. It is formed by means of an inner skin, separating the bottom of the balloon from the rest. This compartment occupies about one-tenth of the whole cubic space of the balloon, and serves to keep it stiff, and of the required shape. By these means M. Dupuy de Lôme has attained the two ends he proposed to himself, viz., first, permanence in the shape of the balloon; and, secondly, he has 'been able to give the whole apparatus an axis decidedly parallel to that of the force of propulsion.

Having thus endeavoured to give some account of the new aerial navigator-no easy matter without diagrams-it only remains for us to say a few words about M. Dupuy de Lôme's first experimental trip. There was half a gale of wind blowing at the time he started, and the screw had been slightly damaged. The spirited inventor did not hesitate, however, to make his contemplated ascent. The end justified his confidence; for not only was he able to land near Noyon, in the Department of the Oise, some seventy miles north-east of Paris, but his balloon more than answered his expectations. The screw, when worked by four men, drove the balloon eight kilometres (about five miles) an hour quicker than the rate at which the wind was blowing; so that M. Dupuy de Lôme not only "went like the wind," but actually went faster than the wind. By the use of the rudder the course of the balloon could be altered eleven degrees either way from the set of the wind, making a total deviation of twentytwo degrees. This is, of course, the greatest and most noteworthy result obtained by the new aerial machine. It may possibly be asked, What is the use of the screw when the wind carries your balloon at the rate of fifty-four kilometres, or nearly furty miles an hour? The answer is, that without the screw the rudder would be of little or no use. Every one knows that a ship with. out way on her steerage-way, as it is called, is nearly impossible to steer. And a balloon which has not, like a ship, a second element for the rudder to work on, is still more at the mercy of the wind. The next question is whether the screw cannot be turned by steam instead of by manual labour. But fire and hydrogen gas are bad neighbours, and the introduction of a steam. engine into the car-although it was hazarded some twenty years ago by one of our countrymen, Mr. Henry Giffard-would expose the aeronauts to the dangers of an explosion, followed by a descent to the earth, doubling in rapidity every sixteen feet, in accord. ance with the law of gravitation. Even with a steam-engine on board, there does not seem much cause to fear the "airy navies" of the inventor of ironclad ships just at present. 